Alicante Journal of English Studies 25(2012): 19-32

\title{
Shakespeare: Revising and Re-visioning
}

\author{
Janet Clare \\ University of Hull \\ J.Clare@hull.ac.uk
}

\begin{abstract}
This article engages with one of the current critical and bibliographical concerns of Shakespeare studies: the collaborative nature of Shakespeare's work. Bibliographers have identified other hands in the fabric of Shakespeare's plays. Here the focus is Shakespeare's collaboration in the plays of others. Three such instances will be examined; The Book of Sir Thomas More, The Spanish Tragedy and The Chronicle History of King Lear. Substantially different as these cases may be, in all of them Shakespeare is working with the materials of others. Shakespeare's King Lear is an adaptation of the older Leir play performed by the Queen's Men and in that sense it is a deeply collaborative work. As this essay concludes, without a model there would be nothing to stimulate, or provoke or exceed.
\end{abstract}

One of the major developments in the study of early modern drama over the past two decades has been an increased focus on the collaborative processes through which plays are brought to the public. ${ }^{1}$ Instead of author-centered textual theory, more emphasis is placed on a communally achieved play with a number of contributors in the playhouse and printing house. The quest for a definitive text - whether it be one representative of the author's final intentions or a performance text - has come to be regarded as elusive. We have begun to regard a play as not simply an expression of its author but as shaped by revision and contingent upon auspices of performance and publication. In the case of Shakespeare, the vast amount of scholarship expended on the editing and annotating of his plays has alerted us to textual instabilities. From the 1980s bibliographers began to re-consider the different versions of Shakespeare's plays, so that they were not 
simply regarded as 'good' or 'bad' or as corruptions of an authorial original but as a number of arrested moments in the process from stage to page. James Marino (2011: 74) described the situation pithily "early modern plays were never finished; they were merely sent to the printers". It is recognized that, as is most evident in the textual histories of Hamlet and King Lear, there is no single authoritative version of a play. Shakespeare's plays are laminated; as they have been handed down to us, they reflect multiple collaborations between playwright, actors, scribes, stage and press licensers. Those plays which exist in more than one text suggest revision or adaptation for performance, as well as possible external interventions from censorship or other hands. Revision may be in the hands of dramatists who have nothing to do with the original composition. By the same token Shakespeare had a hand in the work of others.

This essay is a contribution to a view of Shakespeare as a collaborator, a working playwright who revised the material of others. I want to focus on three instances where Shakespeare engaged - locally and comprehensively — with existing plays. The first is Shakespeare's revision - the only part of a play to survive in his hand- of a scene in the anonymous play Sir Thomas More which was censored by the Master of the Revels, probably in the mid 1590s. The second concerns the additions, recently attributed to Shakespeare, to the extremely popular Spanish Tragedy in 1602, and the third is his revisionary adaptation of the old King Leir play in 1606. In the first two, the revision amounts to no more than scenes and passages, while in the re-writing of the anonymous King Leir play Shakespeare is re-working an entire play and in so doing transforming its genre. Substantially different as these cases may be, not only do they demonstrate Shakespeare's involvement in the theatre practices of his day, but they also suggest some common ground, political and commercial, for revising and re-visioning plays.

The one piece of dramatic writing that has survived in Shakespeare's handwriting is an addition to an anonymous play, The Book of Sir Thomas More where he is working as one of a consortium of playwrights and turning his skills to re-writing under the impress of censorship. The play follows the career of Henry VIII's Chancellor, Thomas More, telescoping two quite different narratives: the May Day riots in London in 1517 against foreign workers, and the Reformation politics of Henry's break with Rome. In planning to represent on the stage popular rebellion against an immigrant workforce, the dramatists badly misjudged the moment. The depiction of the riots against foreigners, called "strangers" in the play, provoked a draconian response from the censor, no doubt shaped by the topicality of the material. The rigorous censorship of the play can be seen as part of wider measures to curb hostilities against foreigners working in London. Throughout the manuscript, the censor objected to this sympathetic representation of the origins of the uprising, as well as to the actual rebellion, as is apparent from his marginal directive:

Leave out the insurrection wholly and the cause thereof, and begin with Sir Thomas More at the Mayor's sessions with a report afterwards of his good service done being Sheriff of London upon a mutiny against the Lombards — only by a short report, and not otherwise at your own perils. E. Tilney. ${ }^{2}$ 
'E. Tilney' -Edmund Tilney - was the censor. Censors are not in the least interested in what constitutes a good play, and this is very much in evidence in Tilney's imperatives. If all his strictures were obeyed, nearly a quarter of the play would have been lost. Additions and revised passages bound up with the manuscript suggest that there was some attempt to salvage the play. One of these passages is by Shakespeare. In this scene More enters and entreats the rioters to be calm and compassionate:

Grant them removed, and grant that this your noise

Hath chid down all the majesty of England.

Imagine that you see the wretched strangers,

Their babies at their backs, with their poor luggage,

Plodding to th'ports and coasts for transportation,

And that you sit as kings in your desires,

Authority quite silenced by your brawl,

And you in ruff of your opinions clothed:

What had you got? I'll tell you: you had taught

How insolence and strong hand should prevail,

How order should be quelled. And by this pattern

Not one of you should live an aged man,

For other ruffians, as their fancies wrought.

With selfsame hand, self reasons, and self right,

Would shark on you, and men, like ravenous fishes

Would feed on one another.

(Addition II, 83-98)

He continues by warning them that in rising against the King, who has been lent "his throne", "his sword" and his "own name" by God, they are in fact rising against God himself. In Shakespeare's writing, there is a shift of emphasis from the grievances of the commons to respect for order and degree and the heinousness of rebellion. In revising the image of riot and popular grievance to which the censor had objected, Shakespeare gave the company what they needed: a politically orthodox scene to counter popular xenophobia. Despite the recasting of the riot, it would appear that insufficient ideological counterweight was offered to the forceful representation of treason elsewhere in the play. There is little evidence that the play was ever staged, and it was never published in its own time.

By the time Shakespeare was brought in to help revise the play of Sir Thomas More recognition of his skills as a playwright and as a reviser must have been pretty widespread. Beginning his professional life as an actor, he learnt the craft of playwright from watching and acting in plays and must have retained memories of countless speeches and scenes, noting how effective certain moments were and accumulating a store of theatrical ideas that he could use and re-direct. If current bibliographical thinking is right, he was employed to revise possibly the most popular play of his age. A new revised edition of The Spanish Tragedy was published - eight years after the author's death - in 1602, and the additions were advertised on the title page: 
Newly corrected, amended, and enlarged with new Additions of the Painters part, and others, as it hath of late been divers times acted.

These additions are primarily to the part of Hieronimo, trading on the role which had struck such a chord in the popular imagination some fifteen years earlier. The revised Spanish Tragedy repeated its earlier success; it was reprinted five times in the Jacobean period and supplanted the version of which Kyd seems to have been the sole author. On the whole, more attention has been made to the attribution of the additions than to their content. In 1602 Henslowe (2002: 203) records paying Ben Jonson twelve shillings for a play entitled Richard Crockback and "for new adicyons for Jeronymo". Tantalizingly neither Jonson's Richard III nor his additions to 'Jeronymo' — a popular reference for the play published as The Spanish Tragedy - have survived. Apart from evident stylistic differences, Jonson's authorship is contested on chronological grounds: the additions must have been in circulation well before 1602 when lines from them were mocked in John Marston's Antonio and Mellida (5.1.1-42) published in 1602. Henslowe's record presumably related to further work on the text which did not find its way into print. Various other hands including Shakespeare and Webster have been suggested in the twentieth century. The advent of computer analysis has brought renewed interest in attribution and collaboration, leading to a conclusion that on grounds of style, function words and lexical-word tests it was Shakespeare who enlarged The Spanish Tragedy, ${ }^{3}$ a proposition advanced long ago by S.T. Coleridge. If this was the case, Shakespeare must have been revising The Spanish Tragedy at the time he was working on his own revenge play, Hamlet.

In modern editions, the five additional passages have been seen as interfering with the integrity of the play's design and are relegated to appendices. ${ }^{4}$ Their cultural significance as a reworking of possibly the earliest popular Elizabethan revenge play has been ignored. No doubt, now that Shakespeare's hand has been detected in the revised Spanish Tragedy it will receive renewed and different treatment. In more general terms, there is an opportunity to see revision - or more precisely dramatic expansion - in operation, and consider what the additional material reveals about the dramatic preoccupations informing revision. We could even say that, despite the different scale, the enlarged 1602 Spanish Tragedy provides some sort of template for the expansion of the second edition of Hamlet published in 1604. In both the second edition of Hamlet and the revised Spanish Tragedy the role and dominant traits of the protagonist are extended. All of the new material in The Spanish Tragedy focuses on Hieronimo: his distracted grief at the murder of his son Horatio and his inability to obtain justice. The first addition, for example, interpolates lines after the discovery and cutting down of Horatio's corpse, as Hieronimo refuses to accept that the corpse is indeed that of his son "I wonder how this fellow got his clothes". This is followed in the extended text by the lamenting realization that he is deluding himself:

It was a man, sure, that was hanged up here; [...]

Let me look again. O God! 
Confusion, mischief, torment, death and hell,

Drop all your stings at once in my cold bosom,

That now is stiff with horror; kill me quickly:

Be gracious to me, thou infective night,

And drop this deed of murder down on me:

Gird in me waste of grief with thy large darkness,

And let me not survive to see the light

May put me in the mind I had a son.

Isabella $\mathrm{O}$, sweet Horatio. $\mathrm{O}$, my dearest son!

Hieronimo How strangely had I lost my way to grief! ${ }^{5}$

It is the 'strangeness' of Hieronimo's grief that shapes the extended part, and Shakespeare is responding to the documented stage appeal of Hieronimo, as the father near demented by his cruel loss. This is most apparent in the longest addition and since it is specifically mentioned on the 1602 title page - one noteworthy in performance: the new addition of "the painter's part". The painter may have been conceived to replace Bazulto, the Old Man, who petitions Hieronimo, as Knight Marshall, for justice for his murdered son. The new character of the painter, Bazudo, also has a murdered son. Hieronimo, in his distraction, orders Bazudo to paint a family portrait with the years within a single frame: "let five years go", so that Horatio is represented. Hieronimo's demands become wilder, the mute picture must do the work of theatre: "canst paint a doleful cry?" The painter must capture in his art all the horror of discovering the dead body and Hieronimo's grief and passion:

Draw me like old Priam of Troy, crying. 'The house is a-fire, the house is a-fire as the torch over my head!' Make me curse, make me rave, make me cry, make me mad, make me well again, make me curse hell, invocate heaven, and in the end leave me in a trance; and so forth.

When the painter asks if this is the end, this elicits a distracted, desolate response: "there is no end: the end is death and madness!" Madness is solace: reason is hell, concludes Hieronimo before beating the painter for his inability to bring him to his son's murderers. In this extended scene there is an affinity with Hamlet's encounter with the players: if the player who is moved to tears by the part he is playing had to bear Hamlet's burden of grief he would, according to Q1 Hamlet (Thompson and Taylor, 2007) "turn all his tears to drops of blood" and "amaze the standers-by with his laments" (7.410-11). Both plays engage with the relation of imitatio to reality, contending that there is a depth of feeling which defies expression, in both cases through a more or less grand rhetorical refutation of art's capacity to express the intensity of grief. But, whereas the passage in The Spanish Tragedy with its full-blown rhetoric virtually invites parody (as it was in Antonio and Mellida), Hamlet's "tears of blood" more succinctly limits the reach of representation. If Shakespeare is here a reviser, in his response in kind to the idiom — or Hieronimo's idiom - of The Spanish Tragedy, he is a remarkably skilful one. 
Throughout his career Shakespeare re-imagined old and popular plays, and thus invited the theatre-going public to re-imagine them as well. He was particularly attracted to the dramaturgy of the Queen's Men, adapting three of their history plays in the 1590s. ${ }^{6}$ The last published text of the Queen's Men, The True Chronicle History of King Leir, appeared on the bookstalls in 1606. It was followed two years later by the publication of Shakespeare's play, entered in the Stationers' register as $\mathrm{Mr}$ William Shakespeare his historye of Kynge Lear. King Lear is an adaptation of the Queen's Men's play although it is rarely referred to as such. In her study of adaptation Linda Hutcheon (2006: xxiii) considers the relationship between source and adaptation, commenting that in various case studies the source text is given priority. This is evidently not the case with Shakespeare where the source text is relegated to the margins and Shakespeare is not presented as an adapter. King Lear is nonetheless a revisionary adaptation of the romance history King Leir.

In traditional source studies, critics have been ready to denigrate the old Leir play as sentimental and naïve, and have proved reluctant to acknowledge that King Lear owed much to it. The evaluation of Sidney Lee, the first editor of the old Leir play, is registered in most editorial and critical references to it. For Lee (1909: x), King Leir was "a specimen of the humble average fare which commended itself to the Elizabethan playgoer" and "the clay out of which Shakespeare fashioned the most poignant of all his triumphs in tragic art". Kenneth Muir (1972: xxiv) in his Arden edition quotes Tolstoy's "perverse view" that King Leir is better than Shakespeare's adaptation. Tolstoy preferred "the simple, natural, and deeply touching character of Leir" and the "yet more touching and clearly defined character of Cordella" and felt that the addition in Shakespeare's Lear of the subplot of Gloucester and his sons was superfluous. While there has been some shift in critical opinion - notable when the commentaries of Kenneth Muir and R.A. Foakes, the most recent Arden editor of King Lear, are compared $^{7}$ - and an increased recognition of Shakespeare's debt to the former stage version, no scholar has responded in the vein of Tolstoy or referred as Tolstoy did to Shakespeare's play as an "adaptation". While there has been some shift in critical opinion in more recent editions, it has also been claimed that the old Leir play was published in 1605 to cash in on the success of Shakespeare's version, implicitly diminishing any notion of Shakespeare's indebtedness to it. Although not impossible, this claim would seem unlikely, pushing the date of the composition of King Lear back to a time when Shakespeare was working on other plays and years before its recorded court performance. The argument seems to rest on an unwillingness to accept that a playwright of Shakespeare's towering originality could possibly have read a play about King Lear a short time before he wrote his own.

Even when King Leir is treated as a 'source', the limitations of such an approach with its emphasis on Shakespeare's artistry can be observed in the treatment afforded The True Chronicle History. Shakespeare took the old tragicomedy, or pre-history, pseudo-history, romance (the genre is disputed) and created from it a searing tragedy. I would not disagree with the proposition that The True Chronicle History of King Leir does work on its audience in quite different ways to Shakespeare's play. Its authors 
were writing for a dissimilar theatre, and, as Scott McMillin and Sally-Beth MacLean (1998: 85) have argued, in their study of the Queen's Men and their dramaturgy, print culture and the company were not, on the whole, well matched. Nevertheless, the theatrical exchange between these two plays is far greater than traditional source studies -often dismissive or patronizing in tone- have allowed. In this section I want to explore not only what Shakespeare took from the antecedent Leir play and how the story took shape in the context of Jacobean theatre, but also to consider the old Leir in its own terms, encountering it, as Elizabethan and Jacobean audiences did, as something other than a precursor of the now much more familiar King Lear.

The True Chronicle History of King Leir exhibits the dramaturgical features of the plays belonging to the Queen's Men so well analysed by McMillan and MacLean. It is an original play which has an involving tale to tell, and the achievement in developing a dramatic narrative, character and motive from the sparse details originating from Geoffrey of Monmouth's History of the British Kings through to Holinshed cannot be overestimated. In the latter, as in Monmouth, apart from a summary reference to the sons-in-law opposing Leir and the hostility of his daughters, we learn little of Leir's experience once he has divided his kingdom. This gap is a gift to the playwright who represents Leir, with the loyal Perillus, moving from one daughter to another, tormented by his misjudgements and his rejection of Cordella, although always maintaining a belief in providence. In this hapless situation, causality and responsibility shape his thoughts: Ragan and Gonorill have cause to be kind and grateful, while Cordella whom "causeless" he "did dispossess of all", has not (line 912). ${ }^{8}$ Later, when he thinks the messenger is about to kill him, he requests Perillus to seek Cordella's forgiveness: "For I have wronged her without any cause". Gonorill's and Ragan's ingratitude becomes the measure for judging all human action. If they can be unnatural and murderous to someone who, in Leir's terms, has always been kind to them, then acts of unsolicited loyalty and devotion - displayed by Perillus - are incomprehensible. Although there is little sense of interiority to the characters of King Leir, - there is no involved poetic language to sustain it - the audience is aware of a penitent and wounded obsession as Leir, incredulous that Perillus should chose to share his grief, asks the loyal counsellor "did I ever dispossess my self/And give thee half my Kingdom in good will?" (892), and later he assumes the messenger directed to kill him must have come from France instructed by Cordella at whose hands he has "deserved as ill". The physical journey is something of a journey of the mind. Following the melodrama of aborted murder, in response to Perillus's pious suggestion that they give thanks to God, Leir inclines to despair:

Thou art deceyved; for I am past the best,

And know not whither for to go from hence:

Death had bin better welcome unto me,

Then longer life to adde more misery.

$(1760-63)$ 
This is not the despair of the two old men in King Lear: Lear's existentialist angst ("is there any can tell who I am") and Gloucester's wish to shake his "great affliction of", leading to the black farce of his 'suicide'; it is a practical despair - Leir has nothing to eat or drink, no roof over his head and nowhere to go - and the mood is soon dissipated when the pair decide to go to France in the hope that Cordella will succour them. This simple play of feeling is characteristic of the play. Lear's hallucinations, crazed associative thinking, exclamations and outbursts, culminating in the mock trial of Goneril and Regan, convey sublimated anguish and despair barely hinted at in King Leir.

Although realistic psychological experience is comparatively undeveloped in Leir, there is, as in other plays by the Queen's Men, clear exploration of motive. Gonorill and Ragan are jealous of Cordella. There is brilliant stereotyping in the older sisters' resentment of Cordella and in their subsequent displays of hypocrisy in early interactions with their father. The daughters are effectively individualized with Ragan playing a dominant role in plotting her father's murder. She is given two long soliloquies which have some theatrical panache. The first finds her in selfcongratulatory mood as she luxuriates in her good fortune and new found dominance:

How may I blesse the howre of my nativity,

Which bodeth unto me such happy Stares [...]

I rule the King of Cambria as I please;

The States are all obedient to my will;

And looke what ere I say, it shall be so.

(925-932)

And there is more along the same lines, ending with the assertion that if her father, who is now restraining Gonorill of her will, should come to live with her, she will "send him packing some where else to go". This kind of ego is unusual in being identified with a woman, and Ragan clearly feels trapped by gender. In her last soliloquy she begins by expressing a "hell of conscience" in her breast; this is not, however, because she feels guilt but because she fears that her plot against her father may have backfired and her father and Perillus escaped to make known her "shame". She surmises that the messenger has succumbed to her father's persuasions and denounces such pusillanimous conduct, wishing that she had been made a man. Yet she denounces men in a conceit which grossly perverts both charity and heartlessness:

I sweare, I am quite out of charity

With all the heartlesse men in Christendome.

A poxe upon them, when they are affrayd

To give a stab, or slit a paltry Wind-pipe,

Which are so easy matters to be done.

Well, had I thought the slave would serve me so,

My selfe would have bin executioner.

(1377-1383) 
This is a rather hideous inversion of Lady Macbeth's comment on the murder of Duncan "Had he not resembled my father as he slept, I had done' $t$ ". For Ragan parricide holds no bars. Despite its 'happy' ending, Leir presents extremes of human viciousness frustrated in the end by the agency of providence, but leaves them still at large.

In all the Leir/Lear narratives, the inherently theatrical love trial figures prominently and this scene of the private being brought into the public opens Leir. Much is at stake. The elder daughters play their roles of loving daughters to perfection not only to gain the kingdom, but also the husbands they desire. Actresses playing Gonoril and Regan in Shakespeare's play sometimes perform their parts in the love test as if they are merely repeating lines they have rehearsed beforehand, conveying their insincerity. This interpretation would certainly fit Leir where Gonorill and Ragan have been informed of and are prepared for their father's plans, and self-interestedly play the deeply devoted daughter in public. They are jealous of Cordella's beauty and popularity, and smirk when she is disinherited. Role-playing and deception are part of the play's dramaturgy. Gonorill and Ragan dupe not only their father but their husbands, and relish manipulating them. Their hypocrisy is both comical and vicious. When the messenger arrives from the Gallian king with letters for Leir, Gonorill enquires after her sister, Cordella:

$\begin{array}{ll}\text { Gon } & \text { [...]How doth my sister brooke the ayre of France } \\ \text { Am. } & \text { Exceeding well, and never sicke one houre, } \\ \text { Gon } & \text { Since first she set her foot upon the shore. } \\ \text { Am. } & \text { I am the more sorry. } \\ \text { Gon. } & \text { I hope, not so, Madam } \\ & \text { Didst thou not say, that she was ever sicke, } \\ \text { Am. } & \text { Since the first houre that she arrived there? } \\ \text { Gon. } & \text { Then I mistam, I sayd quite contrary. } \\ \text { Corn. } & \text { Then she is merry, if she have her health. } \\ \text { Am. } & \text { Oh no, her griefe exceeds, untill the time, } \\ & \text { That she be reconcil'd unto her father. } \\ \text { Gon. } & \text { God continue it. } \\ \text { Am. } & \text { What, madam? } \\ \text { Gon. } & \text { Why, her health. }\end{array}$

(II.1394-1408)

Although this is not apparently deep language, the exchange prompts a striking interplay of spontaneous malice and calculated propriety, as an unbridled impulse breaks loose and is quickly brought to order in a semblance of rectitude.

The 'love trial' of King Leir provides a dramatically affective template for the parallel scene in Lear where feelings had to be improvised in public and where the expected outcome is so drastically reversed. In terms of dramaturgy, the other scene in King Lear which registers most explicitly the pull of the old play is the reunion of Lear and Cordelia. Shakespeare wrote a number of scenes of reconciliation, recognizing, no 
doubt, how affective they were on stage. Such moments recur throughout his writings, from The Comedy of Errors to The Tempest. In the old Leir play, the reunion of Leir and Cordella prompted another such scene. Leir and Perilles escape to France where they meet Cordella and the Gallian king disguised as county folk since they are to embark for Britain and escape detection. Leir detects a resemblance of the woman to Cordella, but does not at first recognize her:

\begin{tabular}{|c|c|}
\hline Cor. & But looke, deare father, looke, behold and see \\
\hline & Thy loving daughter speaketh unto thee. She kneeles \\
\hline Leir & $\mathrm{O}$, stand thou up, it is my part to kneele. \\
\hline & And aske forgiveness for my former faults. he kneeles \\
\hline Cor. & O, if you wish I should injoy my breath, \\
\hline & Deare father rise, or I receive my death. he riseth \\
\hline Leir & Then will I rise, to satisfy your mind, \\
\hline & But kneele againe, til pardon be resigned. he kneeles \\
\hline Cor. & I pardon you: the word beseemes not me: \\
\hline & But I do say so, for to ease your knee. \\
\hline & You gave me life, you were the cause that I \\
\hline & Am what I am, who else had never bin. \\
\hline Leir. & But you gave life to me and to my friend, \\
\hline & Whose dayes had else, had an untimely end. \\
\hline Co & You brought me up, when as I was but young. \\
\hline & And far unable for to helpe my selfe. \\
\hline Let & I cast thee forth, when as thou wast but young, \\
\hline & And far unable for to help thy selfe. \\
\hline Co & God, world and nature say I do you wrong, \\
\hline & That can indure to see you kneele so long \\
\hline
\end{tabular}

(2297-2316)

The King of France intervenes:

King Let me breake off this loving controversy, Which doth rejoyce my very soule to see.

Good father, rise, she is your loving daughter. He riseth

(2316-2318)

King and daughter seem to want to outdo each other in expressions of indebtedness. This is the stuff of comedy, of a kind indicated by the phrase "loving controversy", and there is a rough-hewn pathos to this kneeling and rising in time with each rhyming couplet. Homely and unsophisticated as it may be, the scene impressed itself upon Shakespeare, who carries it into his play, utterly transforming it. Lear is brought on stage in a chair to Cordelia, whom he fails to recognise, but - recalling the motif of kneeling and contrition in the earlier play - in a reflex of contrition, he kneels. This is how the scene appears in the first quarto: 


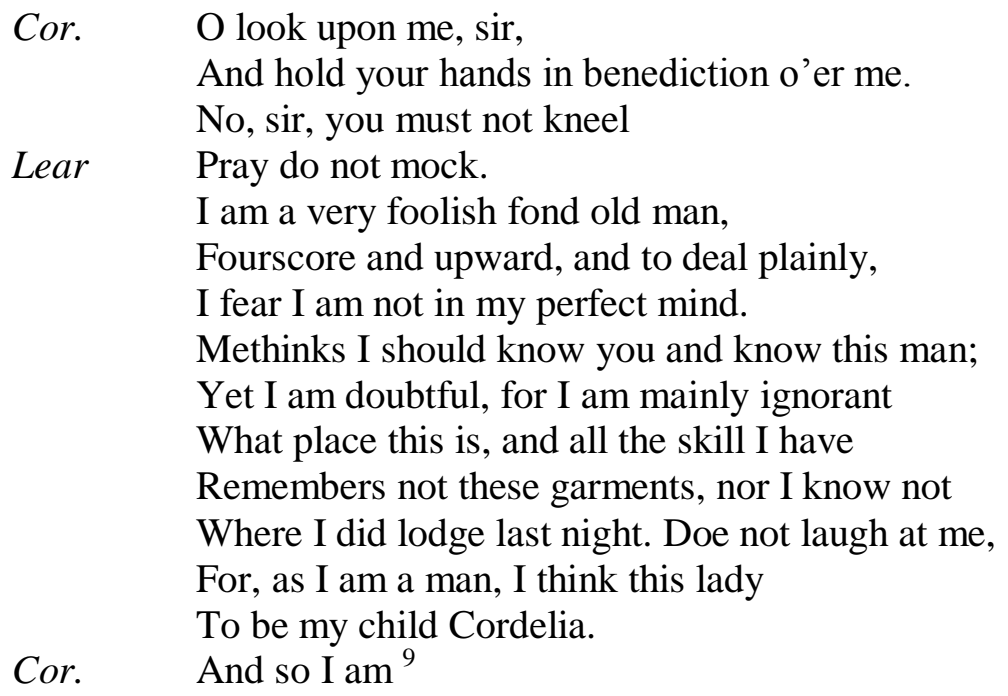

His plea for forgiveness when it comes is confused: "You must bear with me, pray now forget and forgive, I am old and foolish." A scene of recognition is one almost of nonrecognition. This is a motif which Shakespeare repeats, just as effectively, at the end of the play when Kent, hitherto disguised, reveals himself as the loyal servant who has accompanied the King in his adversity. It hardly registers with Lear.

Shakespeare begins his play with the narrative familiar from the old Leir play; his ending is radically different from the earlier play, although not altogether from other historical analogues which report Leir's death, followed by the civil war of the sons of Gonoril and Regan and the suicide of Cordelia. In Leir Cordella with the help of her husband and the French army drives her sisters and their husbands back into their respective kingdoms, restoring Leir to the kingdom he had so foolishly parted with. Justice is done. Gonerill and Ragan are frustrated and defeated, but no one dies. The last lines of the old Leir play are given to Leir:

Come, sonne and daughter, who did me advaunce

Repose with me awhile, and then for Fraunce.

$(1663-4)$

The closing couplet, conveying that all is well and order restored, could not be more different from the final cryptic lines of Shakespeare's play, which are spoken by Albany in the first published version of the text, and allotted to Edgar in the later version:

The weight of this sad time we must obey,

Speak what we feel, not what we ought to say.

The oldest have borne most; we that are young

Shall never see so much, nor live so long.

(5.3. 319-22) 
The words are followed in the Folio by the stage direction "Exeunt with a dead march".

None of the tragic climaxes of Shakespeare's tragedies has such a devastating effect on either its survivors or its audience. It is in the writing of King Lear in the shadow of Leir that Shakespeare's revisionary powers touch on the sublime. He retells this romance Chronicle history to produce the most searing of tragedies. When Lear enters carrying the dead Cordelia, the shock is so terrible that bystanders can only respond as a kind of Chorus of an imminent apocalypse: "Is this the promised end?" asks Kent. "Or image of that horror?" follows Edgar. Albany's words "Fall and cease" convey a sense of existential despair (5.3. 160-61). Nevertheless, as Frank Kermode (1967: 82) has so eloquently put it, "the world goes forward in the hands of exhausted survivors". The tragic re-visioning of the complaisant optimism of the older King Lear story in turn revisions the whole art of tragedy. This is a tragedy which produces the most harrowing of images, as Lear kneels beside the dead Cordelia, deranged in the hope that the feather he holds to her lips will show some life - but "no life at all". There is no consolation for him or for those who surround him.

Previous generations have not been able to take it. As is well known, Naham Tate's adaptation The History of King Lear which reverted to the format of a happy ending, held the stage for 150 years after it was first produced in 1681. Editors, though, had to work with Shakespeare's text. Dr Johnson (1765: 6/158-9), in his edition of Shakespeare, commented:

In the present case the publick has decided. Cordelia, from the time of Tate, has always retired with victory and felicity. And, if my sensations could add any thing to the general suffrage, I might relate, that I was many years ago so shocked by Cordelia's death, that I know not whether I ever endured to read again the last scenes of the play till I understood to revise them as an editor.

That Shakespeare deviated from the Chronicles, as popularized in Leir, seemed more curious even than the play's demonstrable lack of justice. Shakespeare could have spared Cordelia, so why did he not follow the older play and do so? In the twentieth and twenty-first centuries the devastating nature of the tragedy has been re-assessed, as eloquent critical work and the many remarkable, world-wide productions attest. Indeed, it is the very absolute nature of the tragedy, its exploration of extremity, the destruction of the state, its existential angst, its depiction of brutality, hard hearts and innocent victims that has made it seem very much a play of the modern age.

Yet, when the play was first published in 1608 its title page advertised its continuity with the older Leir play: M William Shakespeare His True Chronicle History of the Life and Death of King Lear and his Three Daughters. Placed alone, capitalized and in larger font "his" could be seen as one of the first signs in Shakespeare's work of proprietary authorship. Certainly, the title page is attracting the purchaser's attention to the fact that this is Shakespeare's version of a tale earlier memorialized by the Queen's Men. But the play remains a "chronicle history", drawing attention to its continuity with the older play and missing an opportunity to highlight what for us is its extraordinary generic difference. Even allowing for early modern flexibility of genre, to describe 
Shakespeare's King Lear as a chronicle history still seems a misnomer. This pseudohistory closes with the death of the protagonist, his three daughters and several courtiers. His younger daughter is an innocent victim. Two old men have suffered mentally and physically - almost beyond endurance for their lack of judgment, selfawareness and gullibility. One of them becomes mad with grief and anger. This is one way of looking at the first published edition of King Lear. Yet, the declared generic intertextuality of the old Leir play and the quarto of 1608 may not have seemed so anomalous in the early seventeenth century as it does now. Chronicle history is premised on the death and succession of monarchs, and accordingly King Lear represents the end of the reign of a king who possessed little personal or political judgment and whose decisions, against the advice of counsellors, produce a civil war and a foreign invasion. The foreign power is defeated and the old king is succeeded by a duke who brings peace and unity to an exhausted land.

King Lear was Shakespeare's last attempt at revising another play, and it is of course substantially different from the piece work in Sir Thomas More and The Spanish Tragedy. In neither of these cases is revision aesthetic or generic. The power of Shakespeare's Lear is incontestable, whereas Leir does not begin to plumb the same depths. However, like the two earlier cases, Shakespeare is working with the materials of others, and in that sense King Lear is a deeply collaborative work. Without the play provided by the anonymous author of Leir there would have been no dramatic model to respond to and radically reshape.

\section{Notes}

1. See, for example, Jeffrey Masten (1997) and Janette Dillon (1994). For authorial collaboration, see Brian Vickers (2002). A rather different perspective on collaboration is offered by Tiffany Stern (2009).

2. John Jowett (2011:139) All references are from this edition. He also dates the play and its censorship at a date later than I do, 415-32.

3. See Hugh Craig (2009) and Brian Vickers's (2011).

4. See Philip Edwards (1986) and J.R. Mulryne, ed., revised with a new introduction by Andrew Gurr, (2007). Neither editors or reviser contemplate Shakespeare's authorship of the revisions .

5. J. R. Mulryne (2007): "Scenes added to The Spanish Tragedy in the edition of 1602". 124-37. All quotations are from this edition. The 1602 edition has yet to be edited.

6. The Troublesome Reign of King John, The True Tragedy of Richard the Third and The Famous Victories of Henry the Fifth.

7. Foakes does not include a section on 'sources' in his edition, instead preferring “influences, topicalities and Shakespeare's reading" (1997: 92-110). Foakes rejects the word 'source' as too narrow and too specific in relation to the many echoes of other works in the play. He acknowledges, nonetheless, that the old play had "a powerful impact on Shakespeare, whose close reading of it suggests that he studied the printed book" (1997: 90).

8. The History of King Leir. Malone Society Reprints, 1907. All quotations are from this edition. 
9. All quotations are from Jay L. Halio's edition (1994).

\section{References}

Craig, Hugh (2009): "The 1602 Additions to The Spanish Tragedy". In Shakespeare, Computers, and the Mystery of Authorship. Hugh Craig and Arthur F. Kinney, eds., Cambridge: Cambridge University Press

Dillon, Janette (1994): “Is There a Performance in this Text?", Shakespeare Quarterly. 45:1, 74-86.

Edwards, Philip, ed. (1986): The Spanish Tragedy. The Revels Plays. Manchester, Manchester University Press.

Foakes, R.A., ed. (1997): King Lear. London: The Arden Shakespeare. Third Series.

Halio, Jay L., ed., (1994): The First Quarto of King Lear. Cambridge: Cambridge University Press.

Henslowe's Diary (2002): Second edition, R.A. Foakes, ed., Cambridge: Cambridge University Press.

Hutcheon, Linda (2006): A Theory of Adaptation. London: Routledge.

Johnson, Samuel, ed. (1765): The Plays of William Shakespeare. London. 8 vols.

Jowett, John, ed., Sir Thomas More. London: The Arden Shakespeare, 2011.

Kermode, Frank (1967): The Sense of an Ending: Studies in the Theory of Fiction. Oxford: Oxford University Press

Lee, Sidney, ed., (1909): The True Chronicle History of King Leir: the Original of Shakespeare's King Lear. Chatto and Windus: London.

Marino, James J. (2011): Owning William Shakespeare: the King's Men and their Intellectual Property. Philadelphia: University of Pennsylvania Press.

Marston, John (1991): Antonio and Mellida, W. Reavley Gair, ed., Manchester: Manchester University Press.

Masten, Jeffrey (1997): "Playwrighting: Authorship and Collaboration". In A New History of Early English Drama, John D. Cox and David Scott Kastan, eds., New York: Columbia University Press, 357- 382.

McMillin, Scott and Sally-Beth MacLean: (1998): The Queen's Men and their Plays. Cambridge: Cambridge University Press.

Muir, Kenneth, ed. (1972): King Lear. London: Methuen.

Mulryne, J.R., ed., (2007): The Spanish Tragedy. revised by Andrew Gurr. New Mermaids, London: A\&C Black.

Stern, Tiffany (2009): Documents of Performance in Early Modern England. Cambridge: Cambridge University Press.

Thompson, Ann and Neil Taylor, eds. (2007): Hamlet. The Texts of 1603 and 1623. London: The Arden Shakespeare. 3rd. Series.

Vickers, Brian (2002): Shakespeare, Co-Author. Oxford: Oxford University Press. (2011): "Shakespeare and Authorship Studies in the Twenty-First Century", Shakespeare Quarterly, 2011, 106-42. 